\title{
HISTOCHEMISTRY OF SYNOVIUM IN EXPERIMENTAL HAEMARTHROSIS IN THE RABBIT
}

\author{
BY
}

\author{
F. N. GHADIALLY and S. ROY \\ From the Department of Pathology, University of Sheffield
}

In a recent publication on experimental haemarthrosis in the rabbit we described many interesting ultrastructural changes that occur in the synovial membrane (Roy and Ghadially, 1966). Two such changes attracted our attention: an increase in the number of intermediate and Type B synovial cells, and the occurrence of many small and large vesicles containing flocculent and granular material. However, the nature and significance of these changes can not be interpreted adequately on ultramicroscopic changes alone.

It seemed to us that a histochemical investigation designed to study the variation in the RNA and mucopolysaccharide content of the synovium during the experimental period would assist in determining more precisely the significance of these changes.

Such an investigation has now been carried out and the results are reported in this paper.

\section{Material and Methods}

This study was executed on the tissues collected during our previous experiments (Roy and Ghadially, 1966) and hence a detailed account of experimental procedures and techniques employed will not be repeated here.

Paraffin blocks of synovial membrane obtained from 27 rabbits at various time intervals after the injection of blood into the right knee joint were available for this study. Blocks of synovium obtained from the left knee served as normal controls. These tissues were fixed in 10 per cent. neutral formalin for 24 to $48 \mathrm{hrs}$.

Multiple sections were cut from each of these blocks and stained with haematoxylin and eosin, toluidine blue

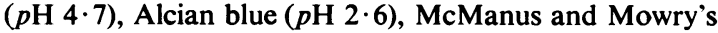
modification of Hale's colloidal iron reaction (McManus and Mowry, 1960), and methyl green-pyronin stains.

\section{Results}

Acid Mucopolysaccharide Staining.-Staining for acid mucopolysaccharide (AMP) with both Alcian blue and colloidal iron methods yielded closely similar results. In normal synovial membrane, the synovial matrix, subsynovial tissue, and a few synovial cells show a faintly positive reaction (Fig. 1). In the case of experimental haemarthrosis, synovial cells and the matrix showed a slight increase in the positive reaction even after $2 \mathrm{hrs}$ of intra-articular injection

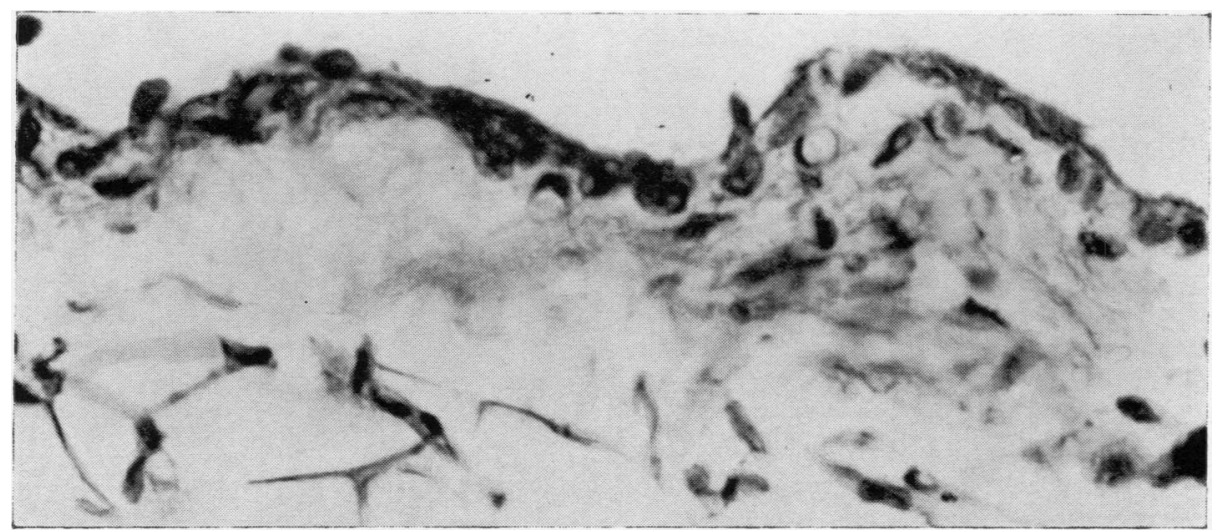

Fig. 1.-Normal rabbit synovium, showing a faintly positive reaction for AMP. Mowry's colloidal iron. $\times 500$. 


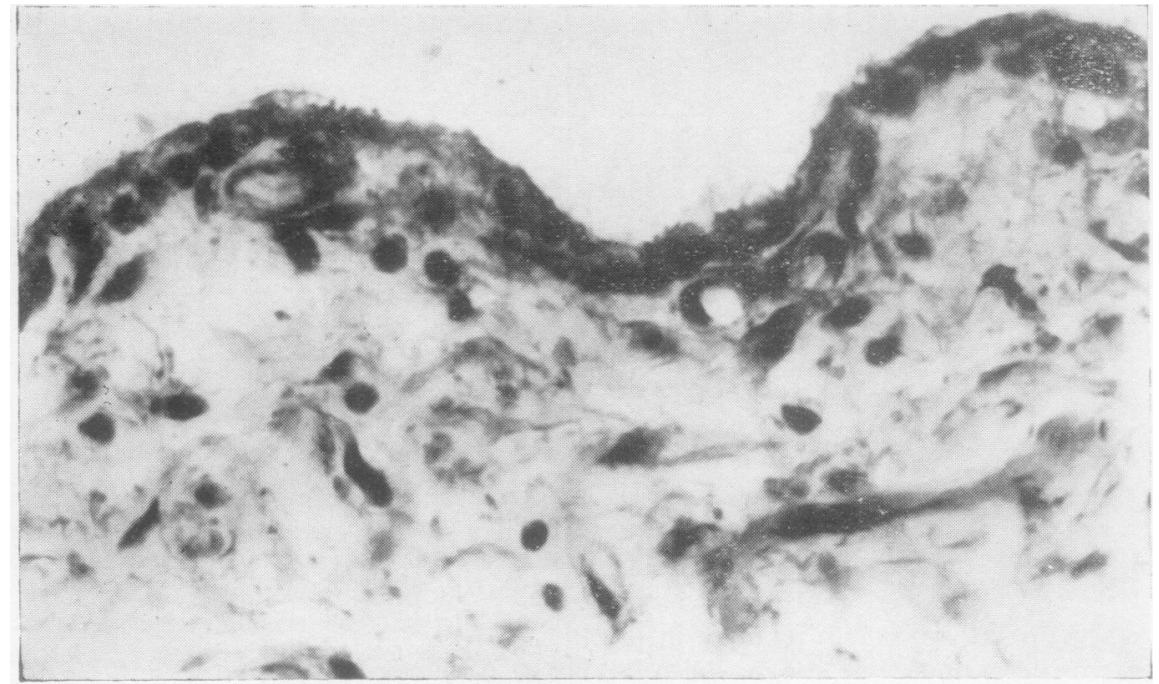

Fig. 2.-Synovium $8 \mathrm{hrs}$ after injection of blood. Note marked increase in staining reaction for AMP. Mowry's colloidal iron. $\times 500$.

of blood. This increased staining reaction is quite clear cut at $8 \mathrm{hrs}$ and involves many more cells in the synovial layer (Fig. 2). At this stage the intensity of reaction in the matrix and superficial subsynovial tissue is also slightly but definitely increased. At 24 hrs the synovial cells, matrix, and superficial and deep subsynovial tissue show a strong and diffuse positive reaction. After $24 \mathrm{hrs}$ of intra-articular injection of blood, the cells gradually become negative to Alcian blue and colloidal iron, but the matrix and superficial and deep subsynovial tissues remain intensely positive.

At $48 \mathrm{hrs}$ some of the specimens showed two clearcut zones of positive reaction (Fig. 3), one located in the synovium and superficial subsynovial tissue, the other placed deeply in the subsynovial tissue. At 72 hrs the picture was similar in that two stained bands were frequently encountered. In later specimens the intensity of reaction in the superficial band gradually decreased until the 7th day when little staining could be detected in this region. The disappearance of staining reaction in the deeper zone was more patchy for even at 7 days occasional intensely stained areas could be detected in this region. The reaction for acid mucopolysaccharide was completely inhibited by pretreatment of the tissue with testicular hyaluronidase (B.D.H.) at pH 6 (Fig. 4, opposite).

Toluidine blue gave only faint metachromasia in small areas of the matrix and subsynovial tissue. No mast cells were seen.

After 48 hrs the synovial cells showed a slight increase in positive reaction to PAS. This increase

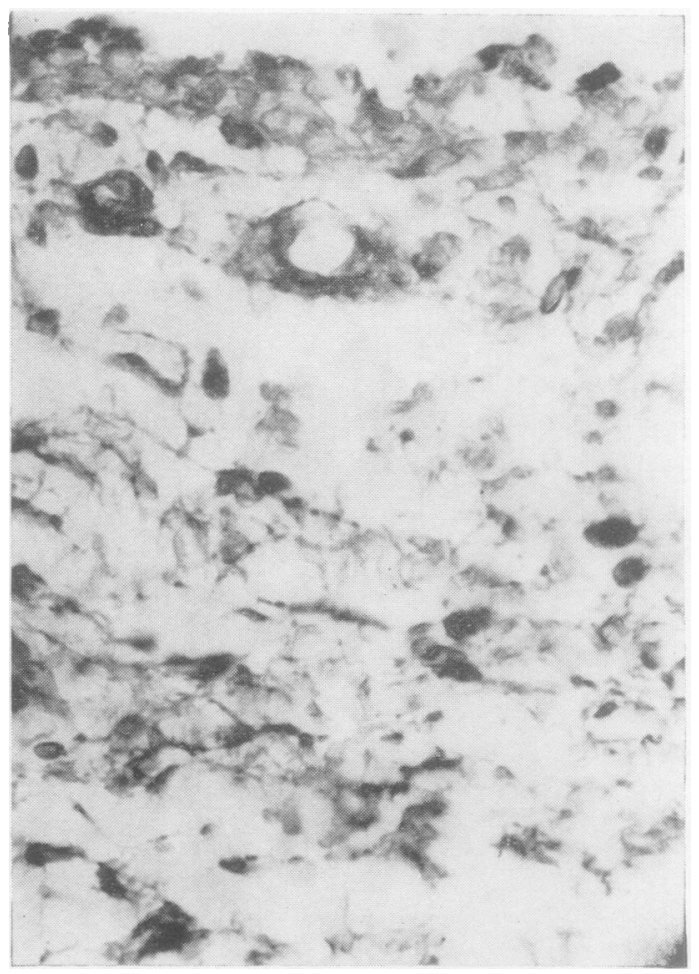

Fig. 3.-Synovium $48 \mathrm{hrs}$ after injection of blood. Two zones of positive staining reaction for AMP can be identified, one lying in the synovium and superficial subsynovial tissues, and the other in the deeper subsynovial tissue. The two zones are separated by a clear area. Mowry's colloidal iron. $\times 425$ approx. 


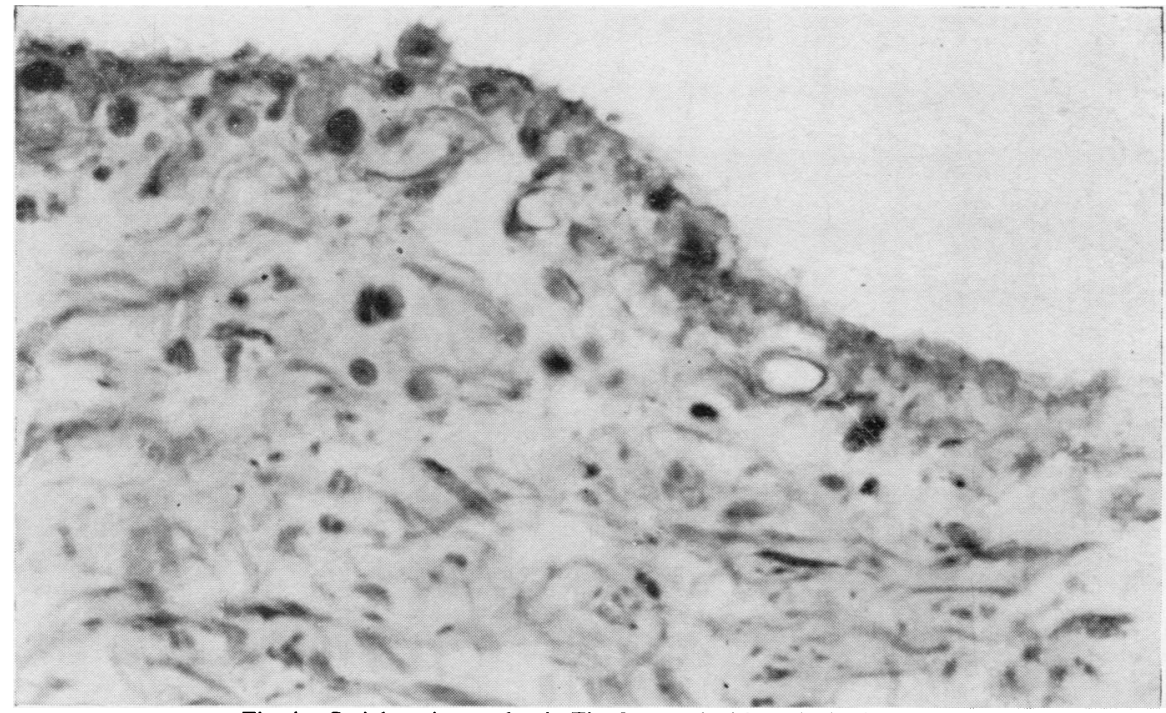

Fig. 4. - Serial section to that in Fig. 2 treated with testicular hyaluronidase, showing absence of staining reaction for AMP. Mowry's colloidal iron. $\times 500$.

became more marked in the later stages and remained so to the end of the experiment.

RNA Staining.- In the normal synovium only a few synovial cells showed a faintly positive reaction (Fig. 5) and this was so also in the case of specimens collected at 2, 4, and $8 \mathrm{hrs}$ after injection of blood into the joint cavity. At 24 hrs there was a small but definite increase in the number and intensity of staining reaction in the synovial cells. The increase became quite marked at $48 \mathrm{hrs}$ (Fig. 6, overleaf) and persisted unabated in all later specimens This staining reaction could be completely eliminated by pretreatment of the sections with RNA-ase (Fig. 7, overleaf).

\section{Discussion}

The purpose of this discussion is to correlate the established morphological changes in the synovium in haemarthrosis (Roy and Ghadially, 1966) with functional alterations suggested by the histochemical studies reported in this paper.

After the injection of blood many synovial cells

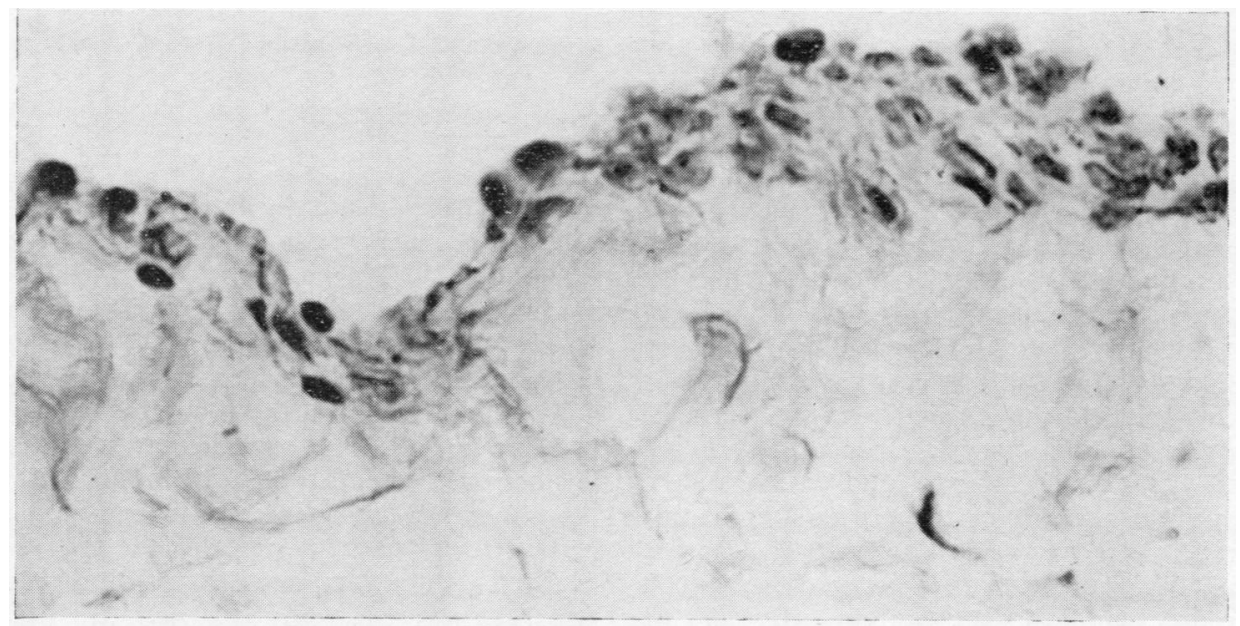

Fig. 5.-Normal rabbit synovium. Only a few synovial cells show a faintly positive reaction for RNA. Methyl green-pyronin. $\times 500$. 


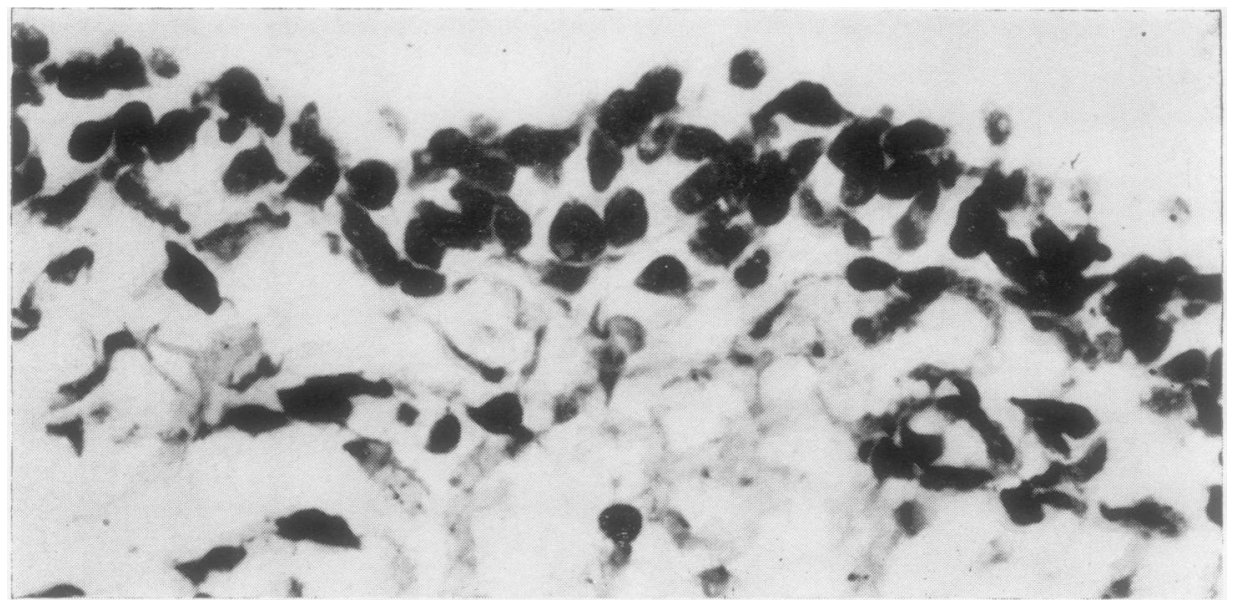

Fig. 6.-Synovium $48 \mathrm{hrs}$ after injection of blood. Almost all the synovial cells show an intensely positive reaction for RNA. Methyl green-pyronin. $\times 500$.

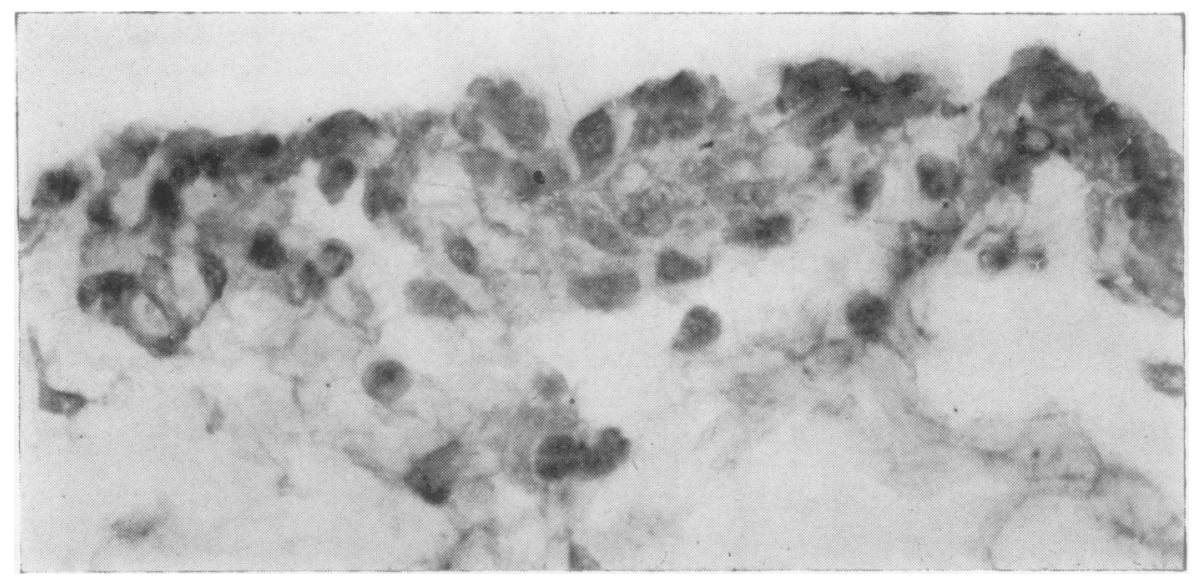

Fig. 7. - Serial section to that in Fig. 6 treated with RNA-ase, showing
absence of staining reaction for RNA.

show large single membrane-bound vacuoles containing flocculent and granular material set in an electron lucent matrix. Such large vacuoles are not found in the normal rabbit synovial cells. However many small vesicles containing similar or more electron dense granular material are often encountered.' It has long been suggested that some of these vesicles contain mucopolysaccharides (Lever and Ford, 1958; Wyllie, More, and Haust, 1964). The result of our present study tends to support this view, for there is a close correlation between the rise and fall in the population of these and also much larger vacuoles and the site and intensity of the staining reaction obtained by stains for AMP.
Thus the increase in the number and size of vacuoles occurs between 2 and $48 \mathrm{hrs}$ after injection of blood. During the early part of the experimental period ( 2 to $24 \mathrm{hrs}$ ) there is an increase in the amount of histochemically detectable AMP in the synovial cells and the reaction is also quite strong at $48 \mathrm{hrs}$. After this period both the vacuoles and the staining reaction begin to fade away from the synovial cells. Histochemical studies suggest that at least some of the mucopolysaccharide is poured out into the matrix, for from $8 \mathrm{hrs}$ onwards the synovial matrix begins to show an increased staining reaction for AMP. At first the positive reaction is seen in the synovial matrix proper but with the passage of time 
a positive reaction is also seen in the subsynovial tissues. Thus, in the specimens collected between 24 and $72 \mathrm{hrs}$, a strong positive reaction is seen not only in the synovial matrix but also in the subsynovial tissue. After this time the intensity of the reaction diminishes till on the sixth and seventh day the mucopolysaccharide shows a patchy distribution in the deeper subsynovial tissue.

Thus, by correlating the morphological and histochemical studies, we can state that within 2 hrs or so after the injection of blood into the joint the synovial cells are either stimulated to produce an increased amount of AMP or store it in these vacuoles, and that by $8 \mathrm{hrs}$ the material is discharged and begins to appear in the matrix. This process continues till about the second day, but an abundant amount of the discharged material persists in the matrix till the third day. From then on the material is gradually removed and only small patches can be detected at the end of the experiment.

As already noted the initial findings, namely the appearance of many large and small vacuoles and an increased staining reaction for AMP, can be interpreted either as increased storage or increased production, but with the passage of time a stage is reached when a fair number of large vacuoles are present and there is also a marked positive reaction in the matrix. This, combined with the fact that during the early stages there is no apparent decrease of staining reaction in the matrix, supports the idea that there is in fact an increased production of AMP rather than an initial phase of storage of this substance in the cell and a later discharge of the excess into the matrix.

The above explanation is adequate to account for all but one of the observed phenomena, namely, the increase of AMP in the deeper synovial tissues. Here two main possibilities must be considered: that the increase in AMP is due to movement of this substance from the synovial matrix to deeper tissue, or that the AMP in this region is the product of the activity of fibroblasts present in this area. Both explanations are tenable but the latter hypothesis is attractive because by about the third or fourth day active granulation tissue with its accompanying proliferating fibroblasts is much in evidence. That such tissue produces AMP is well known (Jackson, 1955; Mancini, Vilar, Stein, and Fiorini, 1961). Our own observations also support the latter hypothesis, for we found that the strongly positive staining reaction in the matrix was not always continuous with that in the deeper subsynovial tissue, but was separated by a relatively poorly reacting zone. One can argue that, if diffusion to the deeper tissues was the operating mechanism, then an uninterrupted gradient of staining from synovium to deeper tissue should be demonstrated.

Yet another conceivable explanation would be that the subsynovial AMP was derived from mast cells. However, this can be readily ruled out for, no mast cells were seen in toluidine blue stained preparations, either in normal rabbit synovium or in experimental haemarthrosis.

The result of RNA staining by the methyl greenpyronin method correlates well with the marked increase in synovial cells containing much rough endoplasmic reticulum (RER) and many Palade granules (Type B). There was also an increase in the number of intermediate type cells containing both prominent RER and elaborate Golgi systems.

Electron microscopical evidence of an increase in ribonucleoprotein (RNP) can be detected $24 \mathrm{hrs}$ after the injection of blood. Histochemically this increase can also be demonstrated at $24 \mathrm{hrs}$, but it is much increased by $48 \mathrm{hrs}$ most of the synovial cells showing intense positive staining reaction for RNA with methyl green-pyronin. From then on the intensely positive reaction is maintained till the end of the experiment.

It is interesting to note that an increase in RNA is also seen in the synovium of man in cases of traumatic effusion (Roy, Ghadially, and Crane, 1966). Since this reaction was observed in human synovium many weeks after the trauma and presumably also after the absorption of any shed blood, it would seem that these factors are not directly involved in the production of this phenomenon. Furthermore, the fact that an intense staining reaction was seen on the sixth and seventh day of the present experiment, at a time when all the injected blood had been removed, also supports this contention. The only common factor in both these cases (man and rabbit) was the presence of a traumatic effusion and it seems to us that increased RNP is in some way linked to the presence of an effusion rather than any other factor.

In traumatic effusion the protein content of synovial fluid is increased (Ropes and Bauer, 1953; Decker, McKenzie, McGuckin, and Slocumb, 1959; Binette and Schmid, 1965). It is also well known that RER and RNP granules are involved in protein synthesis (Palade, 1961). Hence one could postulate that the capacity of synovial cells to synthesize protein is increased in the present experimental condition. Although we have no direct evidence to show actual transfer of protein from the synovial cells into the joint fluid, our findings are quite consistent with the view that the lining synovial cells contribute some proteins into the joint effusion. 


\section{Summary}

A correlation of histochemical and ultrastructural studies in experimental haemarthrosis in the rabbit reveals that there is an increased production of AMP by synovial cells which is later poured out into the matrix and probably into the joint cavity. There is also an increase of AMP in the deeper subsynovial tissues which is probably derived from proliferating fibroblasts in this region.

Twenty-four hrs after injection of blood into the joint space there was a demonstrable increase in the RNA content of synovial cells and this persisted to the end of the experiment ( 7 days).

This work was supported by a grant from the Arthritis and Rheumatism Council and was carried out with the technical assistance of Miss Elizabeth Parry.

\section{REFERENCES}

Binette, J. P., and Schmid, K. (1965). Arthr. and Rheum., 8, 14 (The proteins of synovial fluid: A study of the $\alpha_{1} / \alpha_{2}$ globulin ratio).

Decker, B., McKenzie, B. F., McGuckin, W. F., and Slocumb, C. H. (1959). Ibid., 2, 162 (Comparative distribution of proteins and glycoproteins of serum and synovial fluid).

Jackson, S. F. (1955.). Nature (Lond.), 175, 39 (Cytoplasmic granules in fibrogenic cells).

Lever, J. D., and Ford, E. H. R. (1958). Anat. Rec., 132, 525 (Histological, histochemical and electron microscopic observations on synovial membrane).

Mancini, R. E., Vilar, O., Stein, E., and Fiorini, H. (1961). J. Histochem. Cytochem., 9, 278 (A histochemical and radioautographic study of the participation of fibroblasts in the production of mucopolysaccharides in connective tissue).

McManus, J. F. A., and Mowry, R. W. (1960). "Staining Methods: Histologic and Histochemical", p. 135. Hoeber, New York.

Palade, G. E. (1961). In "Electronmicroscopy in Anatomy", ed. J. D. Boyd, F. R. Johnson, and J. D. Lever, pp. 176-195. Arnold, London.

Ropes, M. W., and Bauer, W. (1953). "Synovial Fluid Changes in Joint Diseases", pp. 78-82. Harvard University Press, Cambridge, Mass.

Roy, S., and Ghadially, F. N. (1966). Ann. rheum. Dis., 25, 402 (Pathology of experimental haemarthrosis).

$\longrightarrow, \ldots$, and Crane, W. A. J. (1966). Ibid., 25, 259 (Synovial membrane in traumatic effusion. Ultrastructure and autoradiography with tritiated leucine).

Wyllie, J. C., More, R. H., and Haust, M. D. (1964). Lab. Invest., 13, 1254. (The fine structure of normal guinea pig synovium).

Histochimie de la membrane synoviale dans l'hémarthrose expérimentale du lapin

\section{RÉSUMÉ}

Une corrélation entre les études de l'histochimie et de l'ultrastructure des cellules synoviales dans l'hémarthrose expérimentale du lapin montre que leur production des mucopolysaccharides acides est accrue et que ceux-ci sont ensuite déversés dans la matrice et probablement dans la cavité articulaire. Il y a aussi une augmentation des mucopolysaccharides acides dans les tissus infrasynoviaux plus profonds, qui résulte probablement des fibroblastes qui prolifèrent dans cette région.

Vingt-quatre heures après injection de sang dans l'articulation on a observé une augmentation appréciable du contenu des cellules synoviales en ARN persistant jusqu'a la fin de l'expérience ( 7 jours).
Histoquímica de la membrana sinovial en la hermartrosis experimental en el conejo

SUMARIO

Una correlación entre los estudios histoquímicos y ultrastructurales de las células sinoviales en la hemartrosis experimental en el conejo reveló un aumento en la producción de mucopolisacaridos ácidos que más tarde se derraman dentro de la matriz y probablemente dentro de la cavidad articular. Se ve también un aumento de los polisacaridos ácidos en los tejidos subsinoviales más profundos probablemente derivado de fibroblastos que proliferan en esta región.

Veinticuatro horas después de la inyección de sangre en la cavidad articular hubo un aumento demostrable del ARN en las células sinoviales que persistió hasta el final del experimento ( 7 días). 